\title{
Nafir Suriyya in Arab Historiography
}

JENS HANSSEN

Early Arabic historiography of the Nabda focused largely on alBustani as a pioneer of the Arab language reform and revival movement and paid more attention to his literary and scientific output than the less polished and more political Nafir Suriyya. The latter's pamphlet format has also made it an outlier in the historiography on early Arabic newspapers and journalism. But Arabic- and European-language literature did recognize the importance of Nafir Suriyya. Its interpretation has shifted over the course of the twentieth century. George Antonius's foundational study-turned-manifesto of Arab nationalism identified the pamphlets as the "the first germ of the national idea" in Syria:

It was a small weekly [sic] publication called The Clarion of Syria, the first political journal ever published in the country, and was mainly devoted to the preaching of concord between the different creeds and union in the pursuit of knowledge. For knowledge, he argued week after week in the earnest columns of his paper, leads to enlightenment; and enlightenment, to the death of fanaticism and the birth of ideals held in common. A platitude perhaps, but one that Syria had not heard before, and which contained the germ of the national idea. ${ }^{2}$ 


\section{6 / Chapter 3}

Albert Hourani echoed Antonius's patriotic sentiments but insisted that al-Bustani "writes as an Ottoman subject, and there is no hint that he would wish to break away from loyalty to the sultan." Instead, "his appeal is to those who belong to a smaller unit within the empire and, as with [the Egyptian reformer] Tahtawi, the unit is a territorial one." In Hourani's interpretation, "'Syria' as a whole is his watan" and al-Bustani "is perhaps the first writer to speak of 'Arab blood.' If Syria was to flourish again, they must love her, and, what is no less urgent, they must be on friendly terms with each other." Compared to other mid-nineteenth-century Arab intellectual giants, "al-Bustani lays his emphasis on religious freedom and equality, and mutual respect between those of different faiths." Hourani explains this move with al-Bustani's Protestant conversion, which he saw as a form of "self-exile [that] may well have turned his mind to the thought of some wider community to which he could belong." al-Bustani distinguished "between two different types of religion: between the fanaticism (ta'assub) which has ruined Syria, and the mutual respect between faiths which should exist and did once exist." Finally, Hourani invokes al-Bustani's belief in the emancipatory potential of civilization: "If Syria is to be truly civilized, she needs two things from her rulers: just and equal laws suited to the times, looking to the matter at issue and not to the person, and based on a separation between religious and secular realms; and education in Arabic. Syria must not become a Babel of languages as she is a Babel of religions."

al-Bustani confessed how difficult it was to find the right words, language, and narrative to represent adequately what happened during the civil war and what it meant for the future. While his Khutba of 1859 and his Khitab of 1868 were originally delivered as scholarly lectures and retained the assertive style of a religious sermon in published versions, Nafir Suriyya cast 
spells of doubt and constantly gestured toward the unknown and the conditionality of its truth claims. ${ }^{4} \mathrm{He}$ categorized and divided the world into conceptual opposites-past/present, religion/politics, civilization/barbarism, Europe/Africa, victims/perpetrators, civil war/civil society. He separated the financial from the moral-cultural losses (al-khasa'ir al-adabiyya), and then all the losses from the potential gains. What may come across as the work of an accountant's balance sheet is in fact part of al-Bustani's broader approach to try to master, by way of simplification, infinitely complex situations.

Most historians of the Middle East have judged Nafir Suriyya's invocation of al-watan - patriotism-as articulating a protean form of twentieth-century Arab nationalisms. For some, since George Antonius and Albert Hourani, it was the source of progress and independence, while for its detractors it unleashed the destruction of an authentic political order where everyone had known their place.

Hourani's Palestinian contemporaries Abdulatif Tibawi and Hisham Sharabi largely shared his interpretation of Nafir Suriyya as the work of an anguished Christian Arab of the modernizing Ottoman empire. An early historian of American missionaries in the Arab world, Tibawi noticed al-Bustani's support for the Ottoman envoy Fu'ad Pasha's pacifying mission and argued that it was rooted in his "conflicting loyalties" to his former Maronite coreligionists in Mt. Lebanon, on the one hand, and the new Protestant and American community he served in Beirut, on the other. Although Tibawi demonstrated that al-Bustani had become somewhat estranged from the American mission by I860, he still considered Nafir Suriyya's "gospel" style the product of his evangelical milieu, living among American missionaries. ${ }^{6}$ Sharabi, a Palestinian-American political scientist who had been an early member of the Syrian Socialist Nationalist Party, 
focused on Nafir Suriyya as an expression of Christian secularism and emergent Syrian nationalism, and the unifying purpose of the Arabic language as "a common ground where Christian and Muslim could meet." 7

Hourani's student, the late Butrus Abu-Manneh argued in his seminal study from 1980 on al-Bustani's identitarian disposition that the promise of Ottoman liberal reform, religious equality, and participatory rule enshrined in the Hatt-1 Hümayun of 1856 "converted" him once more, this time to Ottomanism. The Ottoman reform decree convinced al-Bustani that the Ottoman state was the most reliable guarantor of bringing about a modern social order in Bilad al-Sham. Like his Palestinian colleagues Tibawi and Sharabi, Abu Manneh identified historical Syria, not Lebanon, as the cultural and national referent: "al-Bustani led the way culturally to Arabism, politically to Ottomanism, and inevitably to Syrian nationalism."

Following Lebanon's descent into politically motivated sectarian violence during the 1970 s and 1980s, some historians reclaimed al-Bustani as a Lebanese patriot against the then dominant Syrianist appropriation. ${ }^{9}$ For the Arabic editor of Nafir Suriyya, Yusuf Quzma Khuri, al-Bustani was a "man before his age" who provided contemporary Lebanon with a blueprint for overcoming civil war. ${ }^{10}$ In the work of Ussama Makdisi, alBustani and his Nafir Suriyya came to be recalibrated in the distinctly Lebanese context of coping with communal violence. Makdisi's work combines Tibawi's critique of the impact of missionaries on the Nabda with Abu Manneh's interest in alBustani's Ottomanism. ${ }^{\text {II }}$ But according to Makdisi, the real lesson contained in al-Bustani's post-I86o thought was for Lebanon to learn: "al-Bustani asserted that the mixture of religion and politics would lead to an inflexible political system that could 
not adapt to new realities, anticipating almost word for word modern-day criticisms of the sectarian political system that dominates Lebanon." ${ }^{12}$

In the aftermath of Syria's descent into civil war and the harrowing refugee crisis today, Nafir Suriyya's frame of reference reminds us that sectarian violence is not an isolated Lebanese phenomenon. al-Bustani himself alluded to the wider afflictions that had struck Aleppo in 1850 , Nablus in 1856, and Damascus in I860. ${ }^{13}$ Indeed, the massacre of Christians in Bab Tuma-many of them refugees from Mt. Lebanon-had two contradictory effects. On the one hand, neither the Ottoman nor the European governments could treat the civil war in Mt. Lebanon in isolation from Bilad al-Sham as a whole. On the other hand, the massacres in Damascus reinforced Maronite claims of more general Muslim hostility against Christians. As Carol Hakim has pointed out, "the Damascus massacres obscured the specific political and socioeconomic factors of the outbreak of hostilities in Lebanon and vindicated the view attributing them exclusively to the baleful designs of an inflamed Muslim fanaticism." ${ }^{{ }_{14}}$ In this sense, Nafir Suriyya's wider Bilad al-Sham lens designated not so much a modern-much less an ancient - possessive territorial framework for the "Syrian nation" as the source of attachment (what Nafir Suriyya refers to as "illat al-dhamm") '5 whose members needed to band together and exchange violent strife with love for the homeland.

Since Makdisi's important interventions, sectarianism, nationalism, and secularism no longer appear in English historiography as conceptual rivals or stages of historical development but as dialectically conditioning one another under the sign of colonial modernity. Makdisi defines sectarianism as "a process through which a kind of religious identity is politicized, even 
secularized, as part of a . . struggle for power. ${ }^{{ }^{16} 6}$ He subjected Ottoman pacification of provincial protests and insurrections to a colonial discourse analysis and coined the concept of "Ottoman Orientalism." ${ }^{17}$ Makdisi's rereading of Nafir Suriyya contrasts al-Bustani's understanding of the civil war in 1860 in Mt. Lebanon and his vision of "future's past" to those of the Ottoman special envoy Fu'ad Pasha. There were competing political agendas between al-Bustani's advocacy of citizenship and the authoritarian Ottomanism of Fu'ad Pasha at play:

Despite their advocacy of Syrian patriotism and Ottoman nationalism, respectively, both interpreted and judged within fundamentally igth century notions of progress. In other words, they both explicitly resisted European imperialism at the same time that they deployed a discourse of national and tribal time, which was itself based on European colonialist thinking that divided the world into advanced and backward nations, peoples, and tribes. ... [al-Bustani] anticipated a question central to non-Western historiography: is it possible to represent an indigenous national past using a decidedly Eurocentric notion of modernity? ${ }^{28}$

Most recently, Makdisi argued that al-Bustani's Arab civilizing discourse and his notion of freedom of consciousness was inspired by Protestant ethics and Christian salvific traditions. al-Bustani challenged both the American missionaries' exclusionary and deeply racist conceptions of Protestant cultural superiority and the homegrown sense of sectarian supremacy espoused by the Maronite clergy. Against such intolerance, Nafir Suriyya stood out for the way it charted a modern path of hybrid identity, equality, and coexistence that allowed for "multiple forms of religiosity." ${ }^{\prime \prime}$

Stephen Sheehi, by contrast, reads Nafir Suriyya as an illustration of the literary and rhetorical construction of modern Arab identity. The framework of critical Nabda studies Sheehi 
established enabled him to take al-Bustani and his Nafir Suriyya out of the Syro-Lebanese geographic and discursive confines and bring both into conversation with intellectual production in Egypt and the wider Arabic-speaking world. Sheehi is critical of al-Bustani's writings that he regards as manifestations of the Nabda's bourgeois sensibilities. Frequently, the social and cultural critique al-Bustani offered his compatriots bore the hallmarks of internalized Orientalism and self-colonization. But a respectfully close, Bakhtinian reading of al-Bustani's three most important reform texts—Khutba fi adab al-'Arab (I859), Nafir Suriyya, and Khitab fi al-bay'a al-ijtima' iyya (I868) - reveal his and other Nahdawis' double consciousness, ${ }^{20}$ the desire to be recognized by the West as equal and coeval on the one hand and a desire to be essentially, indeed, authentically, different.

While al-Bustani's Khutba idealized the Arabic literary past, and his later Khitab were delivered as assertive sermons that measured Arab culture against the ideal of the West, Nafir Suriyya's probing exhortative style and direct appeal to "native sons" and "fellow countrymen" of "Syria" represented an incitement to subjective and individual reform among its readers. Nafir Suriyya's rhetoric distinguished between two groups of "compatriots," enlightened or reformable selves and ignorant and fanatical ones. But this gulf was not absolute; it could be overcome if the latter returned to the fold through love and forgiveness for the greater good of political unity and social concord. ${ }^{21}$ By highlighting the text's affective registers, Sheehi presents al-Bustani's civilizing project as a tentative and fragile process of nationalism. al-Bustani's vocabulary of social analysis - contagion, anxiety, and barbarism-certainly casts him as a liberal thinker, but not as a heroic, visionary intellectual pioneer. Rather he appears as someone driven by fear of 
social transgression and by bourgeois intolerance of subaltern mobilization. ${ }^{22}$

Nafir Suriyya continues to animate debates about the origins of Arab nationalism. Most recently, Nadia Bou Ali has read the civil war in 1860 as a disruption that "the forces of capitalism and the shifting relations of production in Levantine society induced," before positing Nafir Suriyya as an affective response for coping with the socioeconomic fallout. According to this interpretation, al-Bustani read the civil war as a manifestation of cultural atavism that deprived hardworking individuals of their rewards and civil society of its promise. al-Bustani's translationadaptation of Daniel Defoe's Robinson Crusoe, which he published in I86I, has received considerable scholarly attention recently to serve as a key for a new understanding of al-Bustani's postwar reform project. ${ }^{23}$ While for Maya Kesrouany, al-Bustani's version of Robinson Crusoe offers insights into the relationship between Lebanese nationalism and the Nabda's translation movement, for Bou Ali al-Bustani's Crusoe offered a capitalist work ethic that modeled the feeling of guilt and sense of morality of every compatriot on the feats of the novel's shipwrecked protagonist. ${ }^{24}$ Bou Ali argued that "the trope of crisis is the founding and foundational episteme of the nation form for the Arabs." ${ }^{25}$ If al-Bustani conceived the nation form through an act of translation, it is borne out of a postwar state of emergency in which "the liberal subject is construed on a splitting between a demonized self and an innocent "we." ${ }^{26}$

Elizabeth Holt has recently picked up the idea of a capitalism-induced cultural crisis in her monograph Fictitious Capital: Silk, Cotton and the Rise of the Arabic Novel. Drawing on Fawaz (1983), Labaki (1984), Khater (200I), Hanssen (2005b), and Kornbluh (2013), she argues that the emergence of the serialized Arabic 
novel on the pages of the Bustanis' newspapers contains literary representations - in content and form-of economic developments in Beirut, Mt. Lebanon, and Bilad al-Sham. The Ottoman-European free trade agreements between I 838 and I840 set the stage for the influx of European commodities and capital. The silk trade took off in earnest when French investors industrialized Lebanese sericulture in the aftermath of the 1860 civil war of I860. Capital was accumulating in the I860s in Beirut, benefiting international but also local financiers. ${ }^{27}$ She insists, however, that the i86os were a period of cultural optimism. The literary expressions of crisis only set in with the economic downturn in the i87os:

By the early summer of $1870, \ldots$ hopeful plotlines were undermined by the suspense charted not only at the level of form, each serialized installment ever asking readers to wait: the remainder was yet to come, but also by the historical conjuncture, a moment when the very unruliness of global-here especially French — capital was profiting at a quickening pace off the risks entailed in financing and speculating in silk moths and mulberry orchards. ${ }^{28}$

In Iterations of Loss: Mutilation and Aesthetic Form, al-Shidyaq to Darwish Jeffrey Sacks explores the destructive character of the $N a b d a$ 's attempt to find an adequate language, to institutionalize Arabic literature, and to adapt Arabic philology in order to meet the political, economic, juridical, and cultural challenges of colonial modernity. ${ }^{29}$ Under the slogan of "Awake ye Arabs Awake," Nahdawis assumed the role of guardians of the Arab future. ${ }^{3 \circ}$ But with some few exceptions, like al-Bustani's nemesis, Ahmad Faris al-Shidyaq (1804-87), they struggled with the sense of loss. The textual and architectural ruins of past grandeur all around, they asked themselves, where are we today, and what have we missed during our "ignorance" and "slumber" 


\section{4 / Chapter 3}

all these centuries? al-Bustani's writings offered a "simplified" Arabic language that could curate, in anthropocentric fashion, the once-glorious past, capture the ominous signs of the present, and project a better, albeit uncertain, future. And yet, with this ability came the mournful realization that "man's" philological mastery reduced Arabic to serving human utility and to curtailing "the iterative dimensions of language, which give language to exceed both itself and its time." ${ }^{31}$ 